\title{
EFEKTIVITAS PENERAPAN ART THERAPY DALAM MENINGKATKAN SELF-ESTEEM PADA REMAJA DI LEMBAGA "X"
}

\author{
Kurniasih $^{1}$ dan Titi Prantini Natalia ${ }^{2}$ \\ ${ }^{1}$ Fakultas Psikologi, Universitas Tarumanagara Jakarta \\ Email:kurniasih.8821@gmail.com \\ ${ }^{2}$ Fakultas Psikologi, Universitas Tarumanagara Jakarta \\ Email:titinatalia.2015@gmail.com
}

\begin{abstract}
ABSTRAK
Masa remaja adalah suatu masa transisi yang melibatkan sejumlah perubahan biologis, kognitif, dan sosioemosional. Salah satu perubahan yang terlihat adalah dalam cara mereka mengevaluasi diri mereka sendiri yang cenderung menghasilkan penilaian negatif terhadap diri. Cara seseorang menilai dirinya secara umum disebut sebagai self-esteem. Salah satu hal yang mempengaruhi self-esteem pada remaja adalah jenis kelamin, di mana perempuan cenderung memiliki self-esteem yang lebih rendah. Selain itu kondisi ekonomi keluarga yang rendah juga mempengaruhi rendahnya self-esteem seseorang. Berdasarakan penelitian, self-esteem yang buruk pada masa remaja, berkorelasi dengan rendahnya kualitas hidup pada saat dewasa, oleh karena itu diperlukan suatu intervensi untuk memastikan bahwa individu tidak memiliki tingkat self-esteem yang rendah selama masa remaja. Art therapy yang diterapkan pada penelitian ini merupakan upaya untuk meningkatkan self-esteem dari 5 remaja putri di lembaga ' $X$ ' yang berasal dari keluarga dengan kondisi ekonomi rendah. Kelima remaja ini memiliki keyakinan yang kurang akan diri sendiri, memberikan penilaian yang negatif terhadap kemampuan diri, dan sangat sulit berinteraksi dengan orang yang baru. Penelitian ini menggunakan pendekatan kuantitatif, one group design pre-test post-test, di mana alat ukur State Self-Esteem Scale (SSES) dianalisa untuk mengetahui perbandingan hasil sebelum dan sesudah pemberian intervensi. Total skor dari lima partisipan mengalami peningkatan, selain itu hasil observasi dan juga hasil tes DAP menunjukkan adanya peningkatan self-estemm. Berdasarkan hasil tersebut, dapat disimpulkan bahwa Art Therapy cukup baik untuk meningkatkan self-esteem dari lima remaja putri di lembaga ' $X$ '.
\end{abstract}

Kata kunci: art therapy, self-esteem, remaja putri.

\section{PENDAHULUAN}

\section{Latar Belakang}

Masa remaja merupakan salah satu tahap perkembangan manusia yang terletak di antara masa kanak-kanak dan masa dewasa. Tahap ini dimulai dari usia 10 tahun sampai dengan 20 tahun (Santrock, 2011). Seseorang dianggap sebagai remaja, sejak individu yang bersangkutan mengalami kematangan seksual sampai individu tersebut dianggap relatif mandiri. Transisi dari masa kanak-kanak ke masa remaja melibatkan sejumlah perubahan biologis, kognitif, dan sosioemosional (Santrock, 2011). Salah satu perubahan yang banyak tampak adalah dalam cara mereka mengevaluasi diri mereka sendiri. Pada masa kanak-kanak, laki-laki dan perempuan menilai diri mereka dengan sangat positif, namun penilaian ini sangat jatuh saat memasuki usia remaja (Robins et al. dalam Santrock 2011). Bahkan Robins et al. menemukan bahwa remaja perempuan menunjukkan penurunan penilaian diri yang lebih drastis dibandingkan remaja laki-laki. Cara seseorang menilai dirinya tersebut disebut sebagai self-esteem (Santrock, 2011).

Sebuah penelitian longitudinal yang mengukur self-esteem di New Zealand (Trezesniewski et al. dalam Santrock, 2011) pada remaja saat berusia 11, 13, dan 15 tahun dan pada saat usia mereka 26 tahun dilakukan pengukuran terhadap adjustment dan kompetensinya. Hasilnya menunjukkan bahwa orang dewasa yang memiliki kondisi fisik dan mental yang lebih buruk, dengan prospek ekonomi yang juga lebih buruk, dan tingkat perilaku kriminal yang lebih tinggi memiliki selfesteem yang lebih rendah pada saat remajanya. Penelitian lain juga menunjukkan hasil yang senada, di mana anak pada tahap middlehood yang memiliki self-esteem yang baik menjukkan perilaku penyesuaian diri yang lebih baik, ia menjadi seorang yang lebih sociable, dan bertanggung jawab, sedangkan self-esteem yang buruk berhubungan dengan kesulitan dalam penyesuaian diri 
(Marsh, Parada, \& Atotte; Rudolph, Caldwell \& Conley, dalam Berk, 2014). Kemudian, salah satu faktor yang memiliki pengaruh terhadap self-esteem remaja adalah kondisi ekonomi (socioeconomic status) (Berg, Mond, Eisenberg, Ackard \& Neumark-Sztainer, 2010). Dalam penelitian Berg et al. (2010) ditemukan bahwa remaja perempuan dari keluarga dengan status sosial ekonomi yang menengah ke bawah memiliki self-esteem yang lebih rendah dibandingkan dengan remaja perempuan dari keluarga dengan status sosial ekonomi yang tinggi.

Remaja perempuan di Lembaga ' $X$ ' yang sedang memasuki usia remaja juga berada dalam keluarga dengan status ekonomi menengah ke bawah. Selain kondisi ekonomi keluarga yang menengah ke bawah, mereka juga juga memasuki tahap di mana mereka mulai mempertanyakan identitas dan mulai menilai dirinya. Pada umumnya remaja mencari identitas diri dengan bertanya pada orang-orang sekitarnya tentang dirinya atau bergabung dalam kelompok-kelompok teman sebaya. Mereka berusaha mencari tempat ataupun kelompok yang mau menerima dirinya apa adanya. Apabila remaja mampu menemukan lingkungan yang tepat, maka mereka akan memiliki penghargaan yang positif pula terhadap dirinya, namun apabila remaja tidak menemukan tempat atau kelompok yang tepat kemungkinan besar mereka akan memiliki sikap negatif seperti, agresif, pendiam, dan penyendiri.

Saat peneliti melakukan kunjungan awal ke Lembaga ' $X$ ', peneliti dijelaskan bahwa dari 35 anak remaja yang terdaftar di Lembaga ' $X$ ', dengan tingkat ekonomi yang cenderung menengah ke bawah tersebut, 5 diantaranya memiliki keyakinan yang kurang akan diri sendiri yang berdampak pada performa mereka sehari-hari. Ketika diwawancara, guru-guru di Lembaga ' $X$ ' menjelaskan bahwa kelima remaja tersebut menunjukkan perilaku pemalu dan menarik diri saat bertemu dengan orang baru. Mereka tidak akan menjawab jika tidak ditanya terlebih dahulu, bahkan setelah ditanya juga mereka menjawab dengan kalimat yang pendek dan kepala menunduk. Saat diobservasi dalam kegiatan bersama di lembaga ' $\mathrm{X}$ ', kelima remaja tersebut cenderung diam saja jika tidak dipanggil. Selain itu, ketika ditanya mengenai kelebihan yang mereka miliki, mereka cenderung menjawab dengan malu-malu dan mengatakan bahwa mereka tidak mempunyai kelebihan.

Mengingat Self-esteem adalah salah satu variabel yang penting bagi seorang yang memasuki usia remaja. Maka remaja di lembaga ' $X$ ' yang memiliki self-esteem yang rendah tersebut perlu diberikan intervensi. Salah satu intervensi yang dapat digunakan untuk meningkatkan self-esteem adalah art therapy. Art dapat menjadi tempat yang aman di mana diri yang lama berkonfrontasi dengan diri yang baru. Proses pembuatan art memberikan kesempatan kepada seseorang untuk menghargai diri sendiri dengan mengamati apa yang dapat mereka lakukan dan hasilkan (Franklin, 1992). Dalam survei yang dilakukan oleh Reynolds, Nabors, \& Quinlan (dalam Hartz \& Thick, 2005) terhadap penelitian empiris yang diterbitkan dalam mengevaluasi keefektifan terapi seni terdapat enam studi yang menunjukkan peningkatan self-esteem yang signifikan.Keenam penelitian tersebut dilakukan oleh Chin et al.; Green et al.; Omizo \& Omizo; Springer et al.; Tibbets \& Stone; White \& Allen (Hartz \& Thick, 2005).

\section{Rumusan Masalah}

Rumusan masalah dalam penelitian ini adalah, "Apakah penerapan art therapy efektif dalam meningkatkan self-esteem pada remaja putri di Lembaga ' $X$ '?'

\section{METODE PENELITIAN Partisipan}

Penelitian ini melibatkan lima individu yang memiliki karakteristik sebagai berikut: (a) berada dalam tahapan usia remaja, (b) mengikuti kegiatan di Lembaga $\mathrm{X}$ karena kondisi ekonomi 
keluarga rendah, (c) memperoleh skor yang lebih rendah dari 76 pada alat ukur State Self-Esteem Scale dengan skor yang lebih rendah dari 27 pada domain sosial.

\section{Prosedur penelitian}

Sebelum pengambilan data dilakukan, peneliti mengunjungi lembaga "X". Sebelum peneliti melakukan pre-test kepada para subjek, peneliti terlebih dahulu meminta izin kepada pengurus lembaga tersebut. Selanjutnya peneliti melakukan screening dengan meminta subjek untuk mengerjakan persoalan Culture Fair Intelligence Test (CFIT). Berikutnya pemberian pre-test dengan mengadministrasikan Draw-A-Person Test dan State Self-Esteem Scale. Wawancara autoanamnesa dengan kelima remaja juga akan dilaksanakan untuk mengetahui gambaran partisipan. Setelah ditentukan subjek yang sesuai dengan kriteria penelitian, peneliti memberikan informed consent kepada setiap subjek. Peneliti menjelaskan bahwa lembar informed consent diisi terlebih dahulu kemudian dilanjutkan dengan data dan identitas subjek. Setelah itu, intervensi selama 7 sesi diberikan dengan menggunakan art therapy. Pada saat seluruh terapi selesai dijalankan, kedua alat ukur, yakni Draw-A-Person Test dan State Self-Esteem Scale akan kembali diadministrasikan setelah sesi terakhir dari intervensi dilaksanakan sebagai post-test. Hasil pretest dan post-test kemudian akan dibandingkan untuk mengetahui dampak dari program intervensi terhadap tingkat self-esteem dari kelima partisipan.

\section{Desain penelitian}

Desain penelitian yang digunakan adalah kuantitatif, one group pre-test post-test design, di mana kuesioner SSES (State Self-Esteem Scale) dianalisa untuk mengetahui apakah ada peningkatan self-esteem sebelum dan sesudah intervensi diberikan.

\section{Setting lokasi}

Penelitian dilakukan di ruang kelas lembaga ' $X$ ' yang memiliki misi membantu anak-anak dari keluarga yang kurang mampu khusunya dalam bidang pendidikan, seperti biaya sekolah, biaya peralatan sekolah, dan penyediaan les bagi anak-anak sekolah di daerah Cilincing.

\section{Perlengkapan penelitian}

Selama melakukan penelitian, penulis memerlukan lembar biodata, lembar informed consent, buku persoalan CFIT dan lembar jawaban, dan lembar kuesioner State Self Esteem Scale (SSES), alatalat lukis (kertas gambar A3, penghapus, pensil HB, dan pensil warna, cat poster, kuas, palet, lem, kertas origami, dan manik-manik yang akan digunakan oleh partisipan untuk membuat gelang).

\section{Pengukuran}

State Self-Esteem Scale digunakan untuk mengukur dependent variable dari penelitian ini, yakni self-esteem Instrumen ini terdiri dari 20 items pertanyaan yang dikelompokkan menjadi 3 komponen self-esteem, yakni performance self-esteem (mis. 'Saya merasa yakin dengan kemampuan yang saya miliki'), social self-esteem (mis. 'Saya khawatir termasuk dalam kategori orang yang gagal') dan appearance self-esteem ('Saya merasa puas dengan penampilan tubuh saya saat ini'). Tiga belas dari 20 item pernyataan merupakan reverse scored items ('Saya merasa bahwa saya tidak berprestasi atau menunjukkan kinerja yang baik'). Setiap item pertanyaan memiliki 5 pilihan respons yang harus dipilih berdasarkan perasaan individu (STS = Sangat Tidak Sesuai dengan diri saya; TS = Tidak Sesuai dengan diri saya; KK= Kadang-Kadang sesuai dengan diri saya; $\mathrm{S}=$ Sesuai dengan diri saya; $\mathrm{SS}=$ Sangat Sesuai dengan diri saya). 


\section{HASIL DAN PEMBAHASAN}

Total skor State Self-Esteem Scale (SSES) yang diperoleh kelima partisipan sebelum berpartisipasi dalam intervensi berbeda dengan total skor yang didapat setelah mengikuti 7 sesi intervensi. Skor dari kelima partisipan mengalami peningkatan (gambar 1). T yang mendapat skor 65 pada pre-test, memperoleh skor 77 pada post-test. S yang mendapat skor 51 pada pre-test, memperoleh skor 65 pada post-test. A yang mendapat skor 46 pada pre-test, memperoleh skor 58 pada post-test. $\mathrm{J}$ yang mendapat skor 66 pada pre-test, memperoleh skor 78 pada post-test dan C yang mendapat skor 47 pada pre-test, memperoleh skor 64 pada post-test. Total skor dua partisipan (T dan J) setelah posttest lebih dari 76 (skor > 76/100), sedangkan tiga partisipan lainnya (S, A, dan C) mendapat skor total setelah post-test yang tetap kurang dari 76 (skor $<76 / 100$ ).

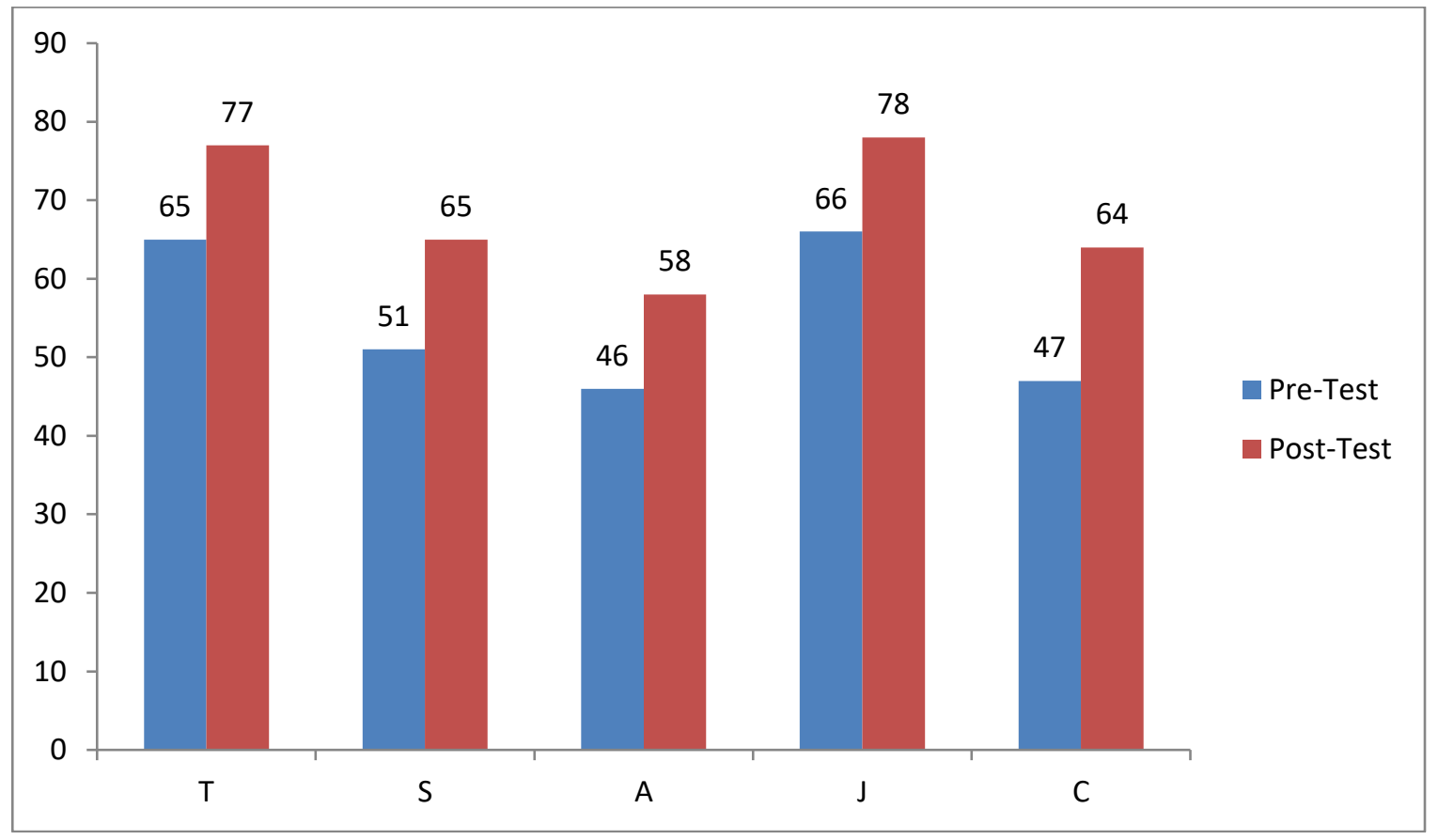

Gambar 1. Total skor SSES pada pre-test dan post-test

Kelima partisipan memperoleh peningkatan skor pre-test dan post-test pada aspek sosial dari SSES. T yang memperoleh skor pre-test 19 pada aspek sosial, meningkat menjadi 26 pada posttest. S yang memperoleh skor pre-test 12 pada aspek sosial, meningkat menjadi 20 pada post-test. A yang memperoleh skor pre-test 15 pada aspek sosial, meningkat menjadi 21 pada post-test. J yang memperoleh skor pre-test 19 pada aspek sosial, meningkat menjadi 28 pada post-test dan C yang memperoleh skor pre-test 12 pada aspek sosial, meningkat menjadi 21 pada post-test. Dua partisipan ( $\mathrm{T}$ dan $\mathrm{J}$ ) memiliki skor pada aspek sosial yang lebih tinggi atau sama dengan 26 (skor $>$ 26/35) (tabel 2) dan tiga partisipan lainnya (S, A, dan C) memperoleh skor di bawah 26 (skor < 26/35). Hal ini sejalan dengan nilai skor total SSES-nya.

Adapun beberapa faktor yang mempengaruhi hasil dari Art Therapy yang diterapkan untuk meningkatkan self-esteem kelima remaja perempuan diantaranya adalah aktivitas menyalurkan perasaan dan harapan para partisipan melalui gambar, dan juga aktivitas menghasilkan sesuatu produk, yaitu gelang, sehingga ketika proses pembuatan art tersebut selesai dan sebuah produk yang unik dihasilkan, remaja terdorong untuk merasa unik juga dan akhirnya remaja akan merasa dirinya berharga (Franklin, 1992). Selain itu homework, yang disertakan selama sesi berlangsung, 
yang memberikan kesempatan bagi pada partisipan untuk me-reivew apa yang telah mereka kerjakan dan menuliskannya dalam jurnal mereka masing-masing sehingga memudahkan mereka untuk melihat kembali dan mengingatkan apa yang sudah mereka pelajar pada sesi-sesi sebelumnya. Terakhir adalah jenis intervensi - yakni intervensi kelompok, di mana melalui aktivitas yang dilakukan di dalam kelompok, remaja belajar dari temannya dan dalam intervensi kelompok, tersedia konteks bagi anggota kelompok untuk berlatih berinteraksi dengan orang lain, kemudian sesama anggota kelompok juga dapat saling memberi dukungan (Liebmann, 2006). Meskipun demikian, kondisi dari ruangan di mana ketujuh sesi diadakan - yakni ruang belajar di Lembaga ' $\mathrm{X}$ ' yang cenderung kecil dan tidak kedap suara, sehingga ketika intervensi dilaksanakan, suara dari ruangan lain terdengar dengan jelas dan berpotensi menghadirkan berbagai extraneous variable (mis. extraneous variable auditori berupa suara guru dan suara anakanak lain yang sedang belajar) yang dapat mempengaruhi atensi maupun kesungguhan partisipan (Magrabi, Li, Dunn \& Coerira dalam Sameve 2017). Suara dari jalan raya di depan ruangan yang juga riuh oleh kendaraan bermotor merupakan faktor distraksi lain yang berpotensi mempengaruhi efektivitas dari intervensi kelompok. Selain itu, intervensi dalam bentuk kelompok meminimalkan atensi yang diberikan kepada masing-masing anggota kelompok, sehingga hubungan terapeutic dengan peneliti kurang terbentuk (Liebmann, 2006).

\section{KESIMPULAN DAN SARAN}

Intervensi kelompok ini dilakukan untuk meningkatkan self-esteem yang dimiliki oleh lima remaja perempuan yang merupakan anak di Lembaga ' $\mathrm{X}$ ' dengan menerapkan Art Therapy. Setelah menjalani 7 sesi art therapy, terlihat adanya peningkatan self-esteem yang terlihat melalui hasil observasi yang menunjukkan peningkatan pada inisiatif serta jumlah partisipasi para partisipan, kemudian kontak mata yang lebih intensif dan volume suara yang lebih keras. Selain itu, hasil post-test pada alat ukur SSES yang menunjukkan peningkatan pada self-esteem kelima partisipan, serta hasil post-test Draw-A-Person Test yang mengindikasikan adanya peningkatan pada selfesteem kelima partisipan. Berdasarkan hasil-hasil tersebut, dapat disimpulkan bahwa Art Therapy cukup baik dalam meningkatkan self-esteem dari lima remaja perempuan di Lembaga ' $X$ '.

\section{Saran kepada peneliti selanjutnya}

Apabila penelitian serupa akan dilakukan, sebaiknya jarak antar sesi dilakukan dengan lebih konsisten, sesi dilakukan di dalam ruangan yang lebih tenang dan terkontrol, kemudian juga rancangan sesi dibuat dengan lebih variatif, sehingga media yang digunakan tidak hanya kertas A3, melainkan lebih merupakan karya yang dapat menghasilkan.

\section{Ucapan Terima Kasih (Acknowledgement)}

Penulis berterima kasih kepada partisipan yang terlibat dalam penelitian ini. Penulis juga mengucapkan terima kasih kepada pihak lembaga ' $\mathrm{X}$ ' yang sangat membantu dalam penyediaan ruangan dan membantu terlaksananya proses terapi.

\section{REFERENSI}

American Art Therapy Association. (2014). Art therapy. Diunduh dari www.arttherapy.org. Berk, L. E. (2014). Development through the lifespan, 6th Edition. Boston : Pearson Education. Franklin, M. (1992). Art therapy and self-esteem. Art Therapy, 9(2), 78-84.

Haluzan. (2012). Art therapy in the treatment of alcoholics. Alcoholism and Psychiatry Research, 30 (1).

Hartz, L., \& Thick, L. (2005). Art therapy strategies to raise self-esteem in female juvenile offenders: A comparison of art psychotherapy and art as therapy approaches. Art Therapy, 22(2), 70-80. 
Liebmann, Marian (2006). Art Therapy for Groups: A Handbook of Themes and Exercises. USA: Brunner-Routledge.

Santrock, J.W (2011). Life span development, 13th Edition. New York: McGraw-Hill Education. Santrock, J.W (2014). Adolescence, Fifteenth Edition. New York : McGraw-Hill Education.

Van den Berg, P. A., Mond, J., Eisenberg, M., Ackard, D., \& Neumark-Sztainer, D. (2010). The link between body dissatisfaction and self-esteem in adolescents: Similarities across gender, age, weight status, race/ethnicity, and socioeconomic status. Journal of Adolescent Health, 47(3), 290-296. 